\title{
NGALAI RITUAL : A COMMUNAL HEALING PERFORMANCE
}

\author{
Mohd Kipli Abdul Rahman ${ }^{1,}$ Nurul Farhana Low Abdullah², Solehah Ishak ${ }^{3}$ \\ ${ }^{1}$ Universiti Pendidikan Sultan Idris (UPSI) \\ ${ }^{2}$ Universiti Sains Malaysia (USM) \\ ${ }^{3}$ Akademik seni budaya dan Warisan Kebangsaan (ASWARA)
}

\begin{abstract}
This study delves into the ngalai ritual performance practiced by Bajau Samah community in Kota Belud, Sabah, Malaysia which serves as a healing method. The study was done using a qualitative approach through the ethnographic strategy application concentrating on the relationship between behaviour and culture. In terms of performance, ngalai is a combination of the elements of dance, singing, music and acting. Traditionally, the ngalai ritual is performed for healing purposes that is based on the animistic religious beliefs which is derived from believe in the existence of spirits (metaphysical entity). Individual who is able to see spirits is said to be capable and have the privilege of curing a disease caused by tulah (plague) due to the interference of spirits. "The community of ngalai practitioners believe that the physical world is influenced by the metaphysical world, especially where it concerned the existence of other worldly beings, the myths and spirits associated with their ancestors. They also believe that the places they inhabit are also shared with the presence of these other worldly, spiritual beings. Based on these beliefs, offerings are prepared and rituals are done in the ngalai performance with the main aim of respecting and asking permission from these spiritual beings to help with the healing process." The healing aspect in ngalai is categorized as communal healing as well as "faith healing", referring to "the ritual practice that relates to religious beliefs and healing" that happen following the method adopted involving patients and the public. Thus, this study seeks to present a justification of ngalai ritual performance that serves as a medium of healing and is still significant in the present context.
\end{abstract}

Keywords: ngalai, ritual, Bajau Samah, tulah, communal healing, faith healing

\section{Introduction}

Kota Belud is a small district located in the northwesterly coast of Sabah (East Malaysia), 70 kilometers off Kota Kinabalu, the capital state of Sabah. The name Kota Belud is believed of have originated from the Bajau language, which is 'kota' meaning the fortress while 'belud' means 'hill'. Thus, Kota Belud is defined as 'a fortress on the hill'. According to narrations, years ago, during war, the people of Bajau made hills as their shelter to rescue them from enemies. For a long time, there were various people who inhabited the district of Kota Belud namely Bajau Samah, Kadazan-Dusun, Cina, Irranun, India and Ubian. However, the people of Bajau Samah constitute the largest population. Up until today, the population of the district of Kota Belud has reached 94,000 persons.

From this, the Bajau ${ }^{1}$ people are generally the second largest group in the state of Sabah. Before the reign of British in the 19-th century, the people of Bajau were nominally placed under the ruling of Brunei and Sulu.

The

\footnotetext{
1 There are various types of Bajau in Sabah, namely Bajau Samah, Bajau Marudu, Bajau Ubian, Bajau Tuaran, Bajau Suluk as well as Bajau Laut. The differences are apparent through the district, their origin and customs. However, the people of Bajau remain in the same society and family.
} 
Bajau people were characteristically maritime, where their skills and knowledge on the sea were never doubted. They were seafarers and lived nomadically, and their source of sustenance depended on sea life. Nevertheless, the Bajau started to move to the land when there were economic activities and they pursued the yields of the forests to survive. For this reason, they selected Kota Belud as their land location until the district was inhabited by the majority of the people of Bajau Samah compared to other districts. The choice of this location as the residential area of Bajau Samah is because the location would be suitable for agricultural-based economic activity.

\section{Bajau Cosmology}

"Universally, the term cosmology is referred to the study of cosmos. Specifically, it is a study that involves complex issues regarding origin of the universe, i.e cosmogyny (Juli 2001; Singaravelu 2001; Hood 2001) and all aspects that related to world order including the existence of supernatural world and beings as well as sociocultural aspects because human beings are also part of the cosmos. Linked to this term is world-view which is defined as a cognitive-based perception or idea about the existence of something, and also concept about attributes, individual self as well as his or her social surroundings (Geertz 2008: 135). Dilthey also defined world-view or weltanshauung as "complex of ideas and sentiments comprising i) beliefs and convictions about the nature of life and the world ii) emotions, habits and tendencies based on these iii) a system of purpose, preferences and principles governing action and giving life unity and meaning" (Symonds 1991:15). The rituals and traditional practices in death customs are often associated with cosmology and world-view because the belief and practices related to death can provide a window for viewing a society's social organization, cultural values and world-view "(Gang Chen 2000).

According to Halina Sendera Mohd. Yakin. (2013), the "Bajau cosmology seems to have four levels or major compositions. God as referred as Latallah resides at the very top (fourth floor) perceived as filled with supernatural joy and beauty over everything on earth, which is deemed to be a paradise. In this place, He occupied the highest hierarchy or level based on the belief that He is the most powerful supernatural being and creator of all creations on earth and this universe. Latallah does not depend on any other creatures, including humans to sustain or complete his existence, but can punish or bless humans and other creatures based on their behaviors. In this supernatural world, there also live angels and malaikat, but they occupy layers below the Latallah. The second level is reserved for the embo', namely the spirits who have passed away long time ago and no longer depends on the conducts or actions of human life for their survival in the new world". "Not only because they had long passed away, but people or family members who were still alive when they left this world may have died and become a spirit or soul, and eventually became the occupant of the same realm. Although the embo' do not depend on the behaviour of the living, they are still respected, feared and remembered among those who are still alive because their title or status and aura still continue to dominate the life and are able to control the actions of living persons. This is because they are believed to always keep eyes on their children, grandchildren or great grandchildren and would advise them if they commit wrong words or wrong behaviours/conducts". "Thirdly, it is a level in which the world is divided into the real world and the supernatural world. As previously mentioned, the real world is inhabited by humans and other concrete objects or events, while the spiritual world is inhabited by supernatural creatures. In the supernatural world, there are particular residencies, namely the zones of air, land and water. In the air zone, there are two spaces which house the soul and spirit. Souls of the dead are placed in a column, while another column, which is above the soul space is allocated for the spirit. The soul will moves to the area of the spirit when the death is reaching 100 days".

\section{Tulah}

Derive from the world view mentioned above, the people of Bajau Samah also believe in the concept of tulah (condemnation), which is the belief that the catastrophe can occur among the people who violate the orders and commands of the King or Sultan and the supernatural. Stemming from animism², Bajau Samah believes that this world is not only inhabited by humans and animals, but also by the supernatural creatures that influence the lives of the humans. They believe that there are good creatures that have extraordinary powers in helping to solve the problems of

\footnotetext{
${ }^{2}$ Animism is the basis of religious belief that first emerged among the primitive man. Animism is the belief that every single thing on this earth has its spirit including the sun and the moon. They also believe that there are spirits and the supernatural who live with them. The animistic belief dictates that every single thing on this earth has its own soul that must be respected so that it will not interrupt humans, but will even help them in their daily affairs.
}

*Corresponding author: kipli@fmsp.upsi.edu.my 
humans and there are evil creatures who give pain and adversaries in humans' lives (tulah). These creatures cannot be seen but their presence can be felt. Individuals who can see through these creatures are thought of as gifted and special, able to heal diseases caused by tulah. Individuals with this specialty will be regarded highly because they can help solve their problems - these people are called shaman or the witch doctors. Nonetheless, it cannot be spread to the public because it is feared that they will be disrupted by evil creatures. Tulah will happen when one commits evil deeds, or those who have violated the rules, for instance:

i. Disobeying parents and not showing any respect to other people

ii. Disturbing the areas of the supernatural.

iii. Disobeying the taboo of the custom.

iv. Hurt other people.

v. Talk badly about something without any valid proof.

In this vein, automatically the concept of tulah forms the societal organizational structure that always remembers and which does not commit anything bad. If one is plagued with tulah, he should see someone who is in good contact with the supernatural to heal his diseases, and this person is the shaman. All the rules and regulations, also taboo commanded by the shaman must be followed to avoid the tulah from being ongoing. The taboo that is always recommended by the shaman is the taboo concerning food and drinks in certain areas thought of the residential areas of the supernatural. "In this vein, the aspect of healing in ngalai is categorised as faith healing, which refers to the ritual practice that relates with the religious beliefs. Healing happens, in respect of the belief towards the spiritual power that has served as the intervention in the healing process" (Mohd kipli Abdul Rahman, 2015).

\section{Ngalai Performance To Heal Tulah}

From the belief on tulah there emerges the ritual performance of ngalai based on animism seeking to achieve healing. "It is a set of patterns from symbolic actions like certain forms of worship, sacrifice, and prohibitions. Rituals are the result of human desire in their pursuit of connection with the supernatural, as humans themselves would naturally possess some religious emotions. In the traditional context, performing arts was also a prevailing form of ritual used in the healing process. Ritual performance is a process that is created from the action or desire to connect with the metaphysical world as they tend to have some religious sentiments. It is also a medium for uniting the intention of the members of the society with a belief through various procedures and actions done symbolically like certain forms that originate from worship, sacrifice, and prohibition. Thus, ritual performance is a ceremony that comes from the action and desire to connect with the supernatural for certain purposes which are normally seeking to obtain good, wellbeing and peace within the practitioners" (Mohd Kipli Abdul Rahman, 2009).

The ritualistic performance often takes three days led by a shaman. According to Mohd Kipli Abdul Rahman, "in the context of the traditional Malay in specific, and the Archipelago in general, the role of the bomoh or shaman is as a mediator or connector between the physical world and the metaphysical world. This is because a shaman has his own strength, where he often has company, or is attached to the supernatural spirits that serve as an entity of the metaphysical world. Thus, a shaman can communicate with the entities from the metaphysical world in the effort to heal diseases believed to have been caused by the spirit" (Narupon Duangwises \& Lowell D. Skar, 2016). This shaman is really respected by the people of Bajau Samah following his skills in healing various diseases using magic. This is because, Bajau Samah believes that rojo ${ }^{3}$ (the supernatural creatures) who cures the patients indeed exists because during the process of healing, the shaman will communicate with rojo. Rojo determines the way that the patient is to be healed, and the things he must avoid throughout his healing period. The shaman in the ritual performance of ngalai often comprises of aging women.

For the purpose of performing for healing purposes, sajian (offerings) which comprise of some foods must be served for the supernatural creature (rojo) called upon to cure the patient. As coined by Mohd Kipli Abdul Rahman, "offerings (sajian) are vital in the healing ritual. The reason why sajian is prepared, is following the belief that there is a spirit (supernatural) that gives life to the ritualistic performance. Thus, when performing this ritualistic dance, the shaman has to ask for the permission first by calling upon the spirit or soul of the ancestors so that the performance will be blessed for healing purposes" (Narupon Duangwises \& Lowell D. Skar, 2016). The foods come in the form of rice,

\footnotetext{
${ }^{3}$ Rojo (king) as the term used by Bajau Samah, is a supernatural creature that helps the shaman in the ngalai healing.

*Corresponding author: kipli@fmsp.upsi.edu.my
} 
young coconut juice, glutinous rice, water and boiled eggs. Sometimes, female white chicken is also prepared as one of the foods served for the rojo. The coconut juice is prepared as drinks while the rice and boiled eggs are the foods for rojo. The foods will be added per request from rojo represented by the shaman. Meanwhile, incense is used to fumigate the performance and the patient areas.

When all is prepared, the ngalai performance will begin with the ceremony 'buka panggung' (the opening of the hall) led by the shaman. The purpose is to steer clear from the disturbance of the evil. The ceremony begins by burning off the incense while fumigating it throughout the whole area and also around the patient and reciting some mantra. Several pieces of fabric were also used in the ceremony comprising of yellow and green clothes. Yellow cloth is used by the shaman to dab the body of the patient and dancers will use the yellow cloth to be wrapped around their waists. The green cloth is used by dancers and patient needs to cover his entire head. The reason or the dancers to wear yellow and green is to incite the spirit of the $\mathrm{r}^{4}$ rojo and his companions to exorcise the bodies of the dancers and the patient himself. The spirit is the handmaiden from the fairyland who accompanies rojo in the ritualistic performance of ngalai.

After the ceremony of 'buka panggung', the shaman will sing, followed by dancers dancing to the rhythm. The musical instrument used is a bamboo and a stick. The song is actually a mantra that calls upon rojo to come and bless the performance and fulfill the request made. Initially, the singing and the dancing follow a slow tempo. However, when it gets to the peak, it becomes increasingly fast and upbeat.

The singing and the dancing will stop when rojo and the shaman begin to interact through the patient's body that has been taken over by rojo. At the same time, the shaman will play his role in controlling the movements of the dancers who are also exorcised by the rojo handmaidens. Meanwhile, the shaman tries to regain the consciousness of the dancers from exorcism and lets them rest while he continues to communicate with rojo. During the process of communication, the shaman will wipe off the patient's face with a yellow cloth and dust off his body as a sign that rojo is present. In the communication, there are several things that the shaman will ask to the rojo, about the root cause of the disease he suffers, how to heal and the taboo. After all is asked, the shaman will recite again the mantra and prayers to extract rojo from the patient's body and send it back to the fairyland.

As it is sent home, the foods called 'pengeras' ${ }^{5}$ are also given as a sign of gratitude to the rojo. It is prepared as requested by rojo. The thing rojo normally asks is the white chicken known as 'ajung'. Ajung will be swept away in the river right after the ceremony of ngalai for the healing to complete. After the ritualistic performance is over, the process of healing will occur and it will take a few days to heal entirely; it also depends on the strength of the patient's body. After the ngalai healing, the patient will feel extremely tired due to the exorcism he experiences. Normally, the family of the patient will hold a blessing ceremony or feast after the healing process so that the patient will heal even faster. The patient needs to adhere to several taboo determined by rojo mediated by the shaman to avoid from any unfortunate incidents or to avoid his disease from becoming ongoing. The healing of patients is seen as the physical and mental capabilities to manage himself or herself as normal.

\section{Ngalai Ritual In Today's Context}

The ritualistic performance of ngalai for healing purposes serves as a method that gives a great influence to patients especially diseases caused by the disturbance of the supernatural (tulah). In this matter, patients have full reliance on the shaman and the public to heal themselves with the help of rojo. Therefore, the process of healing through ngalai is regarded as communal healing based on the method adopted involving the patients and the public. It is a dynamic process done through the collective experiences and experimentation. The main objective of the communal healing process manifested through the ritual of ngalai is to revive the balance between the physical and the metaphysical through the healing of patients caused by tulah. In relation to that, the "aspect of healing in ngalai is also categorised as faith healing, as healing happens in respect of the belief towards the spiritual power that has served as the intervention in the healing process".

\footnotetext{
${ }^{4}$ The soul that exists in all the creatures (things) either dead or alive and which traditionally was believed to be able to give strength or to become evil

${ }^{5}$ Pengeras - is a token of appreciation presented by the patient to the shaman as requested by the embo'-embo' in a form of foods or sometimes money.
}

*Corresponding author: kipli@fmsp.upsi.edu.my 
Thus, in the current context of the people of Bajau Samah who still believe in animism, they also believe in the concept of tulah. Among the people of Bajau Samah there are still individuals known as bomoh or shaman, who have the knowledge to heal diseases inflicted by tulah. The diseases caused by tulah cannot be detected through modern medicine as it relates to the supernatural from the metaphysical universe. The evidence that ngalai is still significant in the context of Bajau Samah is through the practice of the ritualistic performance of ngalai itself which still exists and which is still practised by the people.

\section{Conclusion}

In terms of the performance, ngalai is a combination of elements of dance movements, singing, music and acting. Traditionally, the ritual of ngalai is a performance practice to heal, based on the animistic religion that believes in the existence of the supernatural. Individuals who can see these creatures are said to be very able and they have the specialty in healing diseases caused by tulah following the disturbance of the supernatural. The healing aspect in ngalai is categorized as communal healing as well "as faith healing", referring "to the ritual practice that relates to religious beliefs and healing" that happen following the method adopted involving patients and the public. It is a dynamic process done through the collective experiences and experimentation. This study finds that the ritual of ngalai is a ritualistic artistic performance that functions as a medium of healing and it is still significant in the context today.

\section{Acknowledgments}

The authors acknowledged "Universiti Pendidikan Sultan Idris, Malaysia" and "the Ministry of Higher Education Malaysia for the funding of this research under the Fundamental Research Grant Scheme" (FRGS) 2016-0077-10702 (FRGS/1/2016/WAB04/UPSI/02/2) and "Long Term Research Grant Scheme (LRGS), Ministry of Education Malaysia, 203/PTS/6720007, 203/PTS/6727001, 203/PTS/6727002, 203/PTS/6727003”. Our appreciation also goes to Bajau/Sama' community in Kota Marudu, Kota Belud and Semporna, Sabah, for providing the prime information assistance.

\section{References}

1. "Gang Chen, M.A. (2000). Death Rituals in a Chinese Village: An Old Tradition in Contemporary Social Context. Unpublished $\mathrm{PhD}$ dissertation, The Ohio State University".

2. "Geertz. C. (2008). Tafisiran Budaya/The Interpretation of Cultures. (Trans.). Kuala Lumpur: Institut Terjemahan Negara Malaysia Berhad. (Original work published 1973)".

3. Halina Sendera Mohd. Yakin. (2013). "Cosmology and World-View among the Bajau: The Supernatural Beliefs and Cultural Evolution. Mediterranean Journal of Social Sciences. Vol 4" No 9.

4. "Mohd Kipli Abdul Rahman. (2009). Mabuk mistikal: Semiotik metafizik dalam kuda kepang mabuk. Penang: USM Publisher".

5. "Mohd Kipli Abdul Rahman. (2015). Bebayuh: From healing ritual to traditional performance. IJASOS International E-Journal Of Advances In Social Sciences, 1(2), 136-141. doi:http://dx.doi.org/10.18769/ijasos.75810".

6. Narupon Duangwises \& Lowell D. Skar (Editor). (2016). The Folk Performing Arts in ASEAN. Bangkok: Princess Maha Chakri Sirindhorn Antropology Centre, SAC Publication.

7. "Juli Edo. (2001). Kosmologi Orang Asli: Satu Pemerihalan Tentang Perjalanan Roh. In Yaacob Harun (Ed.), Kosmologi Melayu (pp. 133-146), Kuala Lumpur: Akademi Pengajian Melayu, Universiti Malaya”.

8. "Singaravelu, S. (2001). Kesan kosmogini dan kosmografi India di alam Melayu. ( Yaacob Harun Ed.). Kosmologi Melayu. (pp. 43-51), Kuala Lumpur: Akademi Pengajian Melayu, Universiti Malaya”. 